Kong. Res. J. 1(1) : 46-49, 2014

Kongunadu Arts and Science College, Coimbatore

\title{
IN VITRO EVALUATION OF CRUDE ROOT EXTRACTS OF THE PLANT SPECIES, HYPOCHAERIS RADICATA L. FOR POTENTIAL ANTIBACTERIAL ACTIVITY AGAINST SOME HUMAN PATHOGENIC BACTERIA
}

\author{
Jamuna, $S^{*}$., S. Paulsamy and K. Karthika \\ Department of Botany, Kongunadu Arts and Science College, Coimbatore. \\ *E.mail: sjamunaphd@gmail.com
}

\section{ABSTRACT}

The antibacterial activity of the crude root extracts of the medicinal plant species, Hypochaeris radicata was studied against 15 human pathogen bacteria which includes both Gram-positive and Gramnegative strains by using agar well diffusion method. The chloroform and ethyl acetate extracts displayed broad spectrum activity against all the tested organisms but water extract showed no activity. The petroleum ether and methanol extracts showed only moderate activity. The antibacterial activity of the extracts was compared to the standard Ampicillin. The results of this present study support the plant have good antibacterial potential.

Keywords: Hypochaeris radicata, root extract, antibacterial activity, well diffusion method.

\section{INTRODUCTION}

Finding healing powers in plants is an ancient idea. Over three-quarters of the world population relies mainly on plants and their extracts for health care. The herbal products are today symbolize safety in contrast to the synthetics (Joy et al., 1998). Medicinal plants represent a rich source of antimicrobial agents (Mahesh and Staish, 2008). The effect of plant extracts on bacteria has been studied by many researchers. Therefore, plant extracts and phytochemicals with known antimicrobial properties can be of great significance in therapeutic treatments (Diallo et al., 1999; Erdogrul, 2002; Rojas et al., 2006).

Hypochaeris radicata belongs to the family, Asteraceae. It is native to Europe and also distributed in high hills of Nilgiris, the Western Ghats, India (above $2000 \mathrm{~m} \mathrm{msl}$ ). It has lot of medicinal uses, such as anticancer, antiinflammatory, anti-diuretic and hepatoprotective activity and to treat kidney problems. The earlier report revealed that this species have a good antioxidant property (Jamuna et al., 2012). The milky sap is bitter and the plant is suspected by some of being unwholesome as fodder (Aarssen, 1981). It is high in protein, calcium, copper, sulphur and chloride. The seed is an important constituent in the diet of many farmland birds including linnets (Carduelis cannabina) (Moorcroft et al., 1997). The present study was aimed at to evaluate the antibacterial activity of root extracts of $H$. radicata against 15 pathogenic bacterial strains which include both Gram-positive and Gram-negative types.

\section{MATERIALS AND METHODS}

\subsection{Plant collection and identification}

The roots of $H$. radicata were collected from Kattabettu, Nilgiris, the Western Ghats, India $(2000 \mathrm{~m}$ above msl). The authenticity of the plant was confirmed in Botanical Survey of India, Southern Circle, Coimbatore by referring the deposited specimen. The voucher number is BSI/SRC/5/23/2010-11/Tech.153.

\subsection{Preparation of plant extracts}

The dust free root of $H$. radicata was shade dried and powdered. About $50 \mathrm{~g}$ of coarsely powdered plant material $(50 \mathrm{~g} / 250 \mathrm{ml})$ was extracted in a soxhlet apparatus for 8 to 10 hours, sequentially with petroleum ether, chloroform, ethyl acetate, methanol and water separately in order to extract non-polar and polar compounds (Elgorashi and Van Staden, 2004). The extracts obtained were then concentrated and finally dried to a constant weight. Dried extracts were kept at $20^{\circ} \mathrm{C}$ until further use.

\subsection{Preparation of inoculum}

Stock cultures were maintained at $4^{\circ} \mathrm{C}$ on slopes of nutrient agar. Active cultures for experiments were prepared by transferring a loop full of cells from the stock cultures to test tubes of nutrient agar medium and were incubated without agitation for $24 \mathrm{hrs}$ at $37^{\circ} \mathrm{C}$. The cultures were diluted with fresh nutrient agar broth to achieve optical densities corresponding to $2-10^{6}$ colony forming units $(\mathrm{CFU} / \mathrm{ml})$ for bacteria.

\subsection{Bacterial strains used}

In-vitro antibacterial activity was examined for the root extracts of the species, $H$. radicata against 15 bacterial strains which include the Gram-positive strains viz., Streptococcusfaecalis, S. pyogenes, Enterococcus faecalis, Bacillus subtilis, B. 
thuringiensis and Staphylococcus aureus and Gramnegative strains viz., Seratia marcescens, Klebsiella pneumoniae, Proteus vulgaris, P. mirabilis, Salmonella paratyphi, $S$. parathypi A, $S$. paratyphi B, Pseudomonas aeruginosa and Escherichia coli.

\subsection{Antibacterial assay}

The antibacterial activity of the root extracts was determined by using agar well diffusion method (Cruickshank et al., 1975). The autoclaved media was poured in the sterilized Petri plates. These plates were dried for a period of 20 minutes under aseptic condition before its use. Freshly grown cultures of the tested bacterial strains were streaked over the plates using a platinum wire inoculation loop. On sterile media plates, well of $5.0 \mathrm{~mm}$ diameter were punched with the help of a sterile cork borer. The extracts $(50 \mu \mathrm{g} / \mathrm{mL})$ were added into the wells by using micropipettes. A standard antibiotic, Ampicillin $(50 \mu \mathrm{g} / \mathrm{mL})$ was tested against the pathogens. The plates were incubated at $37^{\circ} \mathrm{C}$ for $24 \mathrm{hrs}$. After the incubation period, the diameter of the inhibition zones of each well was measured in millimeter.

\subsection{Statistical analysis}

The antibacterial activity of $H$. radicata root extracts was indicated by clear zones of growth inhibition. All experiments were performed in triplicate and the results are presented as mean \pm SD (Standard Deviation). The significance in the difference of mean was determined according to New Duncan's Multiple Range Test (Gomez and Gomez, 1976).

\section{RESULTS AND DISCUSSION}

Table 1 shows the effect of various alcoholic and aqueous root extracts of $H$. radicata against the pathogenic bacterial strains studied. Of the five extracts tested chloroform and ethyl acetate extracts showed higher zone of inhibition against all the bacteria. Salmonella paratypi B was very sensitive to ethyl acetate $(25 \mathrm{~mm})$ and chloroform extracts $(23 \mathrm{~mm})$. This bacterium is a type of germ that is found in the intestines of humans and can cause illness. Symptoms happen gradually which may include: fever (usually as high as 103 or $104^{\circ} \mathrm{F}$ ), headache, fatigue (feeling tired), diarrhea (sometimes bloody), stomach pain, serious complications can occur (septicaemia, meningitis), especially in young children and immunocompromised patients (Nagano et al., 2006). Next to that, the another bacterium, Proteus mirabilis was very susceptible to ethyl acetate $(23 \mathrm{~mm})$ and chloroform $(23 \mathrm{~mm})$ extracts. This bacterium is one of the common species of Enterobacteriaceae and well known as a pathogen in urinary tract infections (Warren et al., 1982; Warren et al., 1987). It has been implicated in hospital outbreaks and cases of crossinfection. The zone of inhibition ranged between $\geq 9$ $15 \mathrm{~mm}$ is an indication of strong antimicrobial activity (Rani et al., 2004). The petroleum ether and methanol extracts showed only lesser activity. However, in water extract no activity was found. Several workers have reported that water extract do not have much activity against bacteria (Martin, 1995; Paz et al., 1995; Vlietinck et al., 1995). Significant antibacterial activity was found in chloroform and ethyl acetate extracts as compared with the standard drug, ampicillin against Proteus mirabilis and Salmonella paratyphi B.

From the above results, it can be concluded that the antibacterial activity of the chloroform and ethyl acetate extracts of $H$. radicata exhibited greater activity than that of the other solvent extracts attempted. It may be due to the greater solubility of the phytochemical compounds in these organic solvents (De Boer et al., 2005). Except the water extract all the other extracts showed better antibacterial activity against all the bacterial strains with average zone of inhibition ranged from $6 \mathrm{~mm}$ to $25 \mathrm{~mm}$. The present results revealed that the extract of $H$. radicata was effective against both Grampositive and Gram-negative bacteria. Inhibition mechanisms of plant extracts against bacteria were by interfering with protein synthesis in bacteria, degrading the existing present cell wall or interfering with bacterial cell wall synthesis, and damaging cell membrane of bacteria also (Yasni, 2009). Previous studies reported that many Asteraceae members exhibited greater biological activity (Ahlem et al., 2008, Malarkodi and Manoharan, 2013). According to this study, plant based antibacterial drugs have enormous therapeutic potential as they can serve the purpose with less side effects that are often associated with synthetic antimicrobial agents. The present study provide the scientific information on the plant extract of $H$. radicata and support the usage of root of this plant for curing many bacterial diseases.

\section{CONCLUSION}

The results presented in this study conclusively demonstrate the antibacterial potential of root extracts of $H$. radicata. The chloroform and ethyl acetate extracts justified the uses of curing the infectious diseases caused by pathogenic microbial strains. Hence, it could be used as a source for pharmaceutical substances with antibacterial potential. Further work is aimed at to isolate and identify the specific compounds for the antibacterial agents. 


\section{REFERENCES}

Aarssen, L.W, (1981). The biology of canadian weeds, 50. Hypochaeris radicata L. Canadian Journal of Plant Science, 61: 365-381.

Ahlem Ben Sassi, Fethia Harzallah-Skhiri, Nathalie Bourgougnon, Mahjoub Aouni (2008). Antimicrobial activities of four Tunisian Chrysanthemum species. Indian Journal of Medical Research. 183-192.

Cruickshank, R., J.P. Duguid, B.P. Marmion and R.H.A. Swain, (1975), Medical microbiology.vol. 2, The practice of Medical Microbiology. Edinburgh, Churchill Livingstone, $12^{\text {th }}$ ed.387-391.

Diallo, D., B. Hveem, A.M. Mahmoud, G. Betge, B.S. Paulsen, A. Maiga, (1999). An ethnobotanical survey of herbal drugs of Gourma district, Mali. Pharmaceutical Biology 37: 80-91.

Elgorashi, E.E. and J.V. Staden, (2004), Pharmacological screening of six Amaryllidaceae species. Journal of Ethnopharmacology 90: 27-32.

Erdogrul, 0.T., (2002). Antibacterial activities of some plant extracts used in folk medicine. Pharmaceutical Biology 40: 269-273.

Gomez, K.A. and K.A. Gomez, (1976), Statistical procedure for agricultural research with emphasis of Rice (Los Bans, Philippines International Rice Research Institute),

Jamuna, S., S. Paulsamy and K .Karthika ,(2012)Screening of in vitro antioxidant activity of methanolic leaf and root extracts of Hypochaeris radicata L. (Asteraceae). Journal of Applied Pharmaceutical Science 02 (07): 149154.

Joy PP., J.Thomas, S. Mathew and B.P. Skaria (1998). In Bose TK et al. (eds). Medicinal plants. Naya Prokash Publishers, Calcutta, Tropical Horticulture 2: 449-632.

Mahesh, B. and S. Satish, (2008), Antimicrobial activity of some important medicinal plant against plant and human pathogens. World Journal of Agricultural Sciences.; 4(3): 839-849.

Malarkodi, E. and A. Manoharan. (2013). Study on antibacterial activity of Parthenium hysterophorus L. Journal of Chemical and Pharmaceutical Research. 5(1): 137-139.

Martin, G.J. (1995). Ethnobotany: A methods manual. London, England, Chapman and Hall.
Moorcroft, D., R.B. Bradburry and J.D. Wilson, (1997). The diet of nestling linnets Carduelis cannabina before and after agricultural intensification. Proceedings of the Btighton Crop Protection Conference-Weeds, 923-928.

Nagano,N., S. Oana, Y. Nagano and Y. Arakawa, (2006). A severe Salmonella enterica serotype Paratyphi infection in a child related to a pet turtle. Trachemys scrippa elegans. Japanese journal of infectious diseases 59(2): 132-134.

Paz, E.A., M.P. Cerdeiras, J. Fernanadez, F. Ferrreira, P. Moyna, M. Soubes, A.Vazquez, S. Vero and L. Zunino, (1995). Screening of Uruguayan medicinal plants for antimicrobial activity. Journal of Ethnopharmacololgy 45: 67-70.

Rani, P. and N. Khullar, (2004) Antimicrobial evaluation of some medicinal plants for their anti-enteric potential against multi-drug resistant Salmonella typhi. Phytotherapy Research 18: 670-673.

Rojas, J., V.J. Ochoa, S.A. Ocampo and J.F. Munoz, (2006). Screening for antimicrobial activity of ten medicinal plants used in Colombian folkloric medicine: A possible alternative in the treatment of non-nosocomial infections. BMC complementary and Alternative Medicine 6: 2.

Vlietinck, A.J., L. Van Hoof., J. Totte., A. Lasure., D.Vanden Berghe., R.C. Rwangabo and J. Mvukiyumwami, (1995). Screening of hundred Rwandese medicinal plants for antimicrobial and antiviral properties. Journal of Ethnopharmacology 46: 31-47.

Warren, J.W., D. Damron, J.H.Tenney, J.M. Hoopes, B. Deforge, H.L. Muncie, (1987). Jr Fever, bacteremia and death as complications of bacteriuria in women with longterm urethral catheters. The Journal of Infectious Diseases 155:1151- 8.

Warren, J.W., J.H. Tenney, J.M. Hoopes, H.L. Muncie and W.C. Anthony. (1982). A prospective microbiologic study of bacteriuria in patients with chronic indwelling urethral catheters. The Journal of Infectious Diseases 146(6): 719- 23.

Yasni, S., S. Elvira and H.D. Eva, (2009). Antimicrobial activity of black cumin extracts (Nigella sativa) against food pathogenic and spoilage bacteria. Microbiol Indones 3(3): 146-150. 
Table 1. Antibacterial activity of the root extracts of Hypochaeris radicata against pathogenic bacteria.

\begin{tabular}{|c|c|c|c|c|c|c|c|}
\hline \multirow{2}{*}{ S.No } & \multirow{2}{*}{ Name of the organisms } & \multicolumn{6}{|c|}{ Diameter of the inhibition zone (mm) } \\
\hline & & Control* $^{*}$ & Petroleum ether & Chloroform & Ethyl acetate & Methanol & Water \\
\hline & Gram-positive Bacteria & & & & & & \\
\hline 1. & Streptococcus faecalis & $22.00 \pm 0.10^{\mathrm{a}}$ & $06.00 \pm 0.10^{\mathrm{b}}$ & $14.00 \pm 0.57^{c}$ & $15.68 \pm 0.13^{c}$ & $08.00 \pm 0.10^{\mathrm{b}}$ & - \\
\hline 2. & S. pyogenes & $13.00 \pm 0.50^{\mathrm{a}}$ & $05.33 \pm 0.58^{b}$ & $9.33 \pm 0.58^{\mathrm{bc}}$ & $12.67 \pm 0.52^{c}$ & $10.67 \pm 0.53^{b c}$ & - \\
\hline 3. & Enterococcus faecalis & $20.33 \pm 0.58^{a}$ & $07.33 \pm 0.28^{b}$ & $12.67 \pm 0.53^{b c}$ & $14.00 \pm 0.20^{c}$ & $10.00 \pm 0.15^{b c}$ & - \\
\hline 4. & Bacillus subtilis & $18.67 \pm 0.21^{\mathrm{a}}$ & $06.00 \pm 0.10^{\mathrm{b}}$ & $15.67 \pm 0.51^{c}$ & $10.67 \pm 052^{\mathrm{bc}}$ & $8.67 \pm 0.15^{b c}$ & - \\
\hline 5. & Bacillus thuringiensis & $23.00 \pm 0.20^{\mathrm{a}}$ & $10.00 \pm 0.20^{\mathrm{b}}$ & $13.00 \pm 0.10^{c}$ & $11.67 \pm 0.53^{\mathrm{bc}}$ & $10.00 \pm 0.10 \mathrm{~b}$ & - \\
\hline 6. & $\begin{array}{l}\text { Staphylococcus aureus } \\
\text { Gram-negative Bacteria }\end{array}$ & $22.67 \pm 0.40^{\mathrm{a}}$ & $08.67 \pm 0.52^{b}$ & $18.00 \pm 0.65^{c}$ & $15.67 \pm 0.06^{c}$ & $09.67 \pm 0.53^{\mathrm{b}}$ & - \\
\hline 7. & Seratia marcescens & $18.38 \pm 0.16^{\mathrm{a}}$ & $07.67 \pm 0.58^{b}$ & $13.33 \pm 0.58^{\mathrm{ab}}$ & $9.67 \pm 0.89^{b}$ & $09.00 \pm 0.10^{\mathrm{b}}$ & - \\
\hline 8. & Klebsiella pneumoniae & $21.00 \pm 0.20^{\mathrm{a}}$ & $06.00 \pm 0.10^{\mathrm{b}}$ & $16.67 \pm 0.51^{c}$ & $16.33 \pm 0.16^{c}$ & $09.67 \pm 0.58^{b}$ & - \\
\hline 9. & Proteus vulgaris & $21.00 \pm 0.10^{\mathrm{a}}$ & $06.67 \pm 0.53^{b}$ & $12.00 \pm 0.20^{c}$ & $10.33 \pm 0.58^{\mathrm{bc}}$ & $09.00 \pm 0.10^{b c}$ & - \\
\hline 10. & P. mirabilis & $21.33 \pm 0.15^{\mathrm{a}}$ & $08.33 \pm 0.60^{\mathrm{b}}$ & $23.33 \pm 0.89^{a}$ & $23.00 \pm 0.20^{\mathrm{a}}$ & $09.67 \pm 0.53^{\mathrm{b}}$ & - \\
\hline 11. & Salmonella paratyphi & $21.67 \pm 0.58^{a}$ & $06.00 \pm 0.10^{\mathrm{b}}$ & $11.00 \pm 0.10^{c}$ & $9.67 \pm 0.58 \mathrm{c}$ & $07.33 \pm 0.58^{b}$ & - \\
\hline 12. & S. paratyphi-A & $20.33 \pm 0.58^{a}$ & $05.33 \pm 0.58^{b}$ & $17.00 \pm 0.20^{c}$ & $18.67 \pm 0.21^{\mathrm{c}}$ & $09.00 \pm 0.10^{\mathrm{b}}$ & - \\
\hline 13. & S. paratyphi-B & $22.33 \pm 0.51^{\mathrm{a}}$ & $09.33 \pm 0.53^{b}$ & $23.00 \pm 0.20^{\mathrm{a}}$ & $25.00 \pm 0.20^{\mathrm{a}}$ & $09.00 \pm 0.10^{\mathrm{b}}$ & - \\
\hline 14. & Pseudomonas aeruginosa & $19.67 \pm 0.89^{a}$ & $08.67 \pm 0.89 \mathrm{~b}$ & $12.00 \pm 0.30^{c}$ & $10.67 \pm 0.53^{\mathrm{bc}}$ & $09.67 \pm 0.53^{b c}$ & - \\
\hline 15. & Escherichia coli & $20.00 \pm 0.46^{\mathrm{a}}$ & $06.00 \pm 0.73^{b}$ & $10.33 \pm 0.58^{c}$ & $10.67 \pm 0.80^{c}$ & $11.00 \pm 0.65^{c}$ & - \\
\hline
\end{tabular}

*Ampicillin, '-' indicates no activity.

Values were performed in triplicates and represented as mean \pm SD

Mean values followed by different superscript in a column are significantly different $(p<0.05)$. 